\title{
A Review of Research on the Effects of LREs on L2 Development
}

\author{
Lilliati Ismail $^{1}$ \\ ${ }^{1}$ Department of English Language Studies, IPG Kampus Ilmu Khas, Kuala Lumpur, Malaysia \\ Correspondence: Department of English Language Studies, IPG Kampus Ilmu Khas, Jalan Yaacob Latif, 56000 \\ Cheras, Kuala Lumpur. E-mail: lilliati.ismail@gmail.com
}

Received: January 20, 2016

Accepted: January 25, 2016

Online Published: February 26, 2016

doi:10.20849/aes.v1i1.17

URL: http://dx.doi.org/10.20849/aes.v1i1.17

\begin{abstract}
Swain and Lapkin's $(1998,2001,2002)$ language-related episodes (LREs) have generated greater interest among ESL (English as a Second Language) practitioners and researchers on the effects of addressing linguistic issues during learner-learner interaction in the course of completing pedagogic tasks on interlanguage development. This paper reviews the results of various studies that measured the effects of LREs on L2 development. This paper concludes that LREs could have beneficial effects on L2 learning as reflected by the amount of negotiation and learning opportunities that occurred, the rate of successful outcomes of the repair practices, and L2 achievements in posttests. This paper also suggests that future research could further analyse the exchanges that occur during LREs to gain a greater understanding of interaction-oriented learning opportunities.
\end{abstract}

Keywords: Language-related episodes (LREs), negotiation of form, repair practices

\section{Introduction}

With growing interest in task-based language teaching and learner interaction, there is greater interest in understanding how learner-learner interaction while engaging in language tasks could help learners improve on their L2 use. For example, researchers are interested in how learners recognise gaps in their language use, draw attention to these gaps through negotiation of meaning and negotiation of form, and through repair practices, and consequently, provide modified output. Samuda and Rounds (1993) used the term "critical episodes" to refer to instances in which learners address recently learnt or problematic features of the target language. Identification of these episodes allowed for the systematic categorisation and analysis of L2 learning opportunities. Later, Swain and Lapkin (1998) used the term "Language-related Episodes (LREs)" to refer to any part of a dialogue where language learners talk about the language they are producing, question their language use, or correct themselves or others".

\section{LREs and L2 Development}

In recent years, the term Language-related Episodes (LREs) has been widely used to indicate the segments of learner-learner interaction that address linguistic issues. Much of recent research has investigated the properties of LREs that could contribute to interlanguage development. These include segments of learner interaction during which learners deal with linguistic issues in their attempt to complete language tasks. During LREs, learners might question the meanings of lexical items, question the spelling or pronunciation of a word, question the use of a grammatical form, or correct each other's use of vocabulary, grammar or sentence structure (Swain, 1998; Williams, 1999). LREs have received considerable attention as they "may serve the function of helping students to understand the relationship between meaning, forms, and function in a highly context-sensitive situation" (Swain, 1998). Moreover, LREs may lead to interlanguage development (Donato, 1994; Swain, 1998; Swain \& Lapkin, 1998).

\section{Research on LREs and L2 Development}

Research into LREs provided analyses into their different subcategories such as whether they are meaning-based, grammar-based, or lexis-based. Other areas of analyses included the varying degrees and types of negotiation, the amount of negotiation of meaning that occurred, as well as the amount of production and the level of learner participation as a result of task manipulation. Table 1 shows a summary of recent studies on the facilitative effects of LREs on L2 development 
Table 1. Summary of studies on LREs and L2 development

\begin{tabular}{|c|c|c|c|c|}
\hline Study & $\mathrm{N}$ & Variables & Analysis & Key results \\
\hline Williams (1999) & $\mathrm{N}=8$ & $\begin{array}{ll}\text { - } & \text { Proficiency } \\
\text { - } & \text { Activity }\end{array}$ & $\begin{array}{ll}\text { - } & \begin{array}{l}\text { Focus of LREs } \\
\text { (lexis vs. }\end{array} \\
\text { morphosyntactic) } \\
\text { - } & \text { Initiator of LREs } \\
\text { (self, other } \\
\text { learner, teacher) } \\
\text { - } & \text { Resolution of } \\
\text { LREs } \\
\text { - } \\
\text { Tailor-made } \\
\text { posttest results }\end{array}$ & $\begin{array}{l}\text { - Successfully resolved } \\
\text { LREs resulted in } 40 \% \text { to } \\
94 \% \text { correctly resolved } \\
\text { tailor-made posttest } \\
\text { items. } \\
\text { - } \\
\text { Higher proficiency } \\
\text { learners were more } \\
\text { likely to benefit from } \\
\text { LREs than lower } \\
\text { proficiency learners. }\end{array}$ \\
\hline $\begin{array}{l}\text { Swain \& Lapkin } \\
\text { (2001) }\end{array}$ & $\mathrm{N}=65$ & $\begin{array}{l}\text { Task type: Jigsaw } \\
\text { group vs. } \\
\text { dictogloss group }\end{array}$ & $\begin{array}{l}\text { Focus of LREs } \\
\text { (lexis vs. form) } \\
\text { Average ratings of } \\
\text { written narratives } \\
\text { based on content, } \\
\text { organisation, } \\
\text { vocabulary, } \\
\text { morphology, and } \\
\text { idea units. } \\
\text { Quality of written } \\
\text { narrative }\end{array}$ & $\begin{array}{l}\text { There was no significant } \\
\text { difference in the } \\
\text { occurrence of } \\
\text { lexis-based and } \\
\text { form-based LREs } \\
\text { between the two tasks. } \\
\text { The jigsaw task led to a } \\
\text { greater range of } \\
\text { vocabulary use and } \\
\text { LREs. }\end{array}$ \\
\hline $\begin{array}{l}\text { Garcia Mayo } \\
(2002)\end{array}$ & $\mathrm{N}=14$ & $\begin{array}{l}\text { Task types } \\
\text { (dictogloss vs. } \\
\text { text } \\
\text { reconstruction) }\end{array}$ & $\begin{array}{l}\text { - Frequency of } \\
\text { LREs } \\
\text { - Features of } \\
\text { concern in the } \\
\text { LREs (grammar, } \\
\text { discourse, } \\
\text { intuition, no } \\
\text { explanation) }\end{array}$ & $\begin{array}{l}\text { The text reconstruction } \\
\text { task generated } 8 \text { times } \\
\text { more LREs than the } \\
\text { dictogloss task } \\
\text { Both tasks did not } \\
\text { encourage learners to } \\
\text { use a range of } \\
\text { knowledge sources to } \\
\text { explain the LREs. }\end{array}$ \\
\hline $\begin{array}{l}\text { Lapkin, Swain, \& } \\
\text { Smith (2002) }\end{array}$ & $\mathrm{N}=8$ & 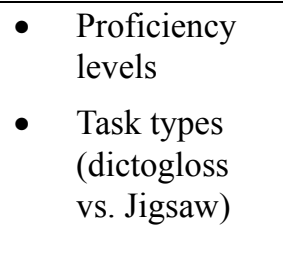 & 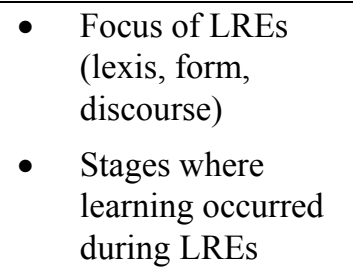 & $\begin{array}{l}\text { The reformulation stage } \\
\text { was found to be useful } \\
\text { in providing learning } \\
\text { opportunities. }\end{array}$ \\
\hline $\begin{array}{l}\text { Swain and Lapkin } \\
(2002)\end{array}$ & $\mathrm{N}=2$ & $\begin{array}{l}\text { Jigsaw story task } \\
\text { (oral and writing) }\end{array}$ & $\begin{array}{ll}- & \begin{array}{l}\text { Focus of LREs } \\
\text { (form, lexis or }\end{array} \\
\text { discourse-based) }\end{array}$ & $\begin{array}{l}\text { - } 47 \text { LREs were produced } \\
\text { during the pre-test } \\
\text { writing stage, } 21 \text { LREs } \\
\text { during the noticing } \\
\text { session, and } 23 \text { LREs } \\
\text { during the stimulated } \\
\text { recall session. } \\
\text { - } \text { Most LREs were } \\
\text { form-based. } \\
\text { Both learners achieved } \\
78 \% \text { correct linguistic } \\
\text { items in the post test. }\end{array}$ \\
\hline
\end{tabular}




\begin{tabular}{|c|c|c|c|c|}
\hline Study & $\mathrm{N}$ & Variables & Analysis & Key results \\
\hline Leeser (2004) & $\mathrm{N}=42$ & $\begin{array}{ll}\text { Task type: } \\
\text { Dictogloss } \\
\text { and passage } \\
\text { reconstructio } \\
\text { n tasks } \\
\text { - } \\
\text { Proficiency } \\
\text { level } \\
\text { (high-high, } \\
\text { high-low, } \\
\text { low-low) }\end{array}$ & $\begin{array}{ll}- & \begin{array}{l}\text { Focus of LREs } \\
\text { (lexis vs. }\end{array} \\
\text { grammar) } \\
\text { - } \\
\text { Outcome of LREs } \\
\text { (successful, } \\
\text { unsuccessful or } \\
\text { abandoned) }\end{array}$ & $\begin{array}{l}\text { 138 LREs were } \\
\text { identified } \\
\text { - } 39.86 \% \text { of the total } \\
\text { LREs had a lexical } \\
\text { focus, and } 60.14 \% \text { had a } \\
\text { grammatical focus } \\
\text { (more than half of which } \\
\text { focused on verb } \\
\text { morphology) } \\
\text { - } 76.81 \% \text { of the LREs } \\
\text { with a linguistic focus } \\
\text { were resolved correctly. } \\
\text { As the overall } \\
\text { proficiency of the dyad } \\
\text { decreased, the mean } \\
\text { number of total LREs } \\
\text { also decreased. }\end{array}$ \\
\hline Malmqvist (2005) & $\mathrm{N}=12$ & $\begin{array}{ll} & \text { Individual vs. } \\
\text { group work. } \\
\text { - } & \text { Proficiency } \\
& \text { levels }\end{array}$ & $\begin{array}{ll}- & \begin{array}{l}\text { Focus of LREs } \\
\text { (grammar, content }\end{array} \\
\text { or lexis) } \\
\text { - } & \text { Outcome of LREs } \\
\text { (successful, } \\
\text { unsuccessful or } \\
\text { abandoned) }\end{array}$ & $\begin{array}{l}\text { Group texts were more } \\
\text { syntactically complex } \\
\text { compared to the } \\
\text { individually } \\
\text { reconstructed texts. } \\
\text { - } \quad \text { LREs focused mostly on } \\
\text { grammar (42\%), } \\
\text { followed by content } \\
(31 \%), \text { and lexical items } \\
(27 \%) . \\
\text { Proficiency levels } \\
\text { affected outcomes of } \\
\text { LREs. }\end{array}$ \\
\hline Poole (2005) & $\mathrm{N}=19$ & $\mathrm{n} / \mathrm{a}$ & $\begin{array}{ll}\text { - } & \begin{array}{l}\text { Focus of LREs } \\
\text { (meaning vs. }\end{array} \\
\text { form) }\end{array}$ & $\begin{array}{l}\text { Learners engaged in } \\
\text { LREs on meaning } \\
(89.8 \%) \text { more than form } \\
(10.2 \%)\end{array}$ \\
\hline Adams (2007) & $\mathrm{N}=25$ & $\mathrm{n} / \mathrm{a}$ & $\begin{array}{ll} & \text { Focus of LREs } \\
\text { - } & \text { Tailor-made tests }\end{array}$ & $\begin{array}{l}\text { - Almost } 60 \% \text { of the } \\
\text { LREs included in the } \\
\text { post-test led to L2 } \\
\text { learning. }\end{array}$ \\
\hline Storch (2008) & $\mathrm{N}=22$ & $\begin{array}{l}\text { Level of } \\
\text { involvement }\end{array}$ & $\begin{array}{ll}- & \text { Form-focused } \\
\text { LREs vs. } \\
\text { meaning-focused } \\
\text { LREs }\end{array}$ & $\begin{array}{l}\text { Elaborate engagement } \\
\text { was more facilitative to } \\
\text { learning than limited } \\
\text { engagement. }\end{array}$ \\
\hline Kim (2008) & $\mathrm{N}=32$ & $\begin{array}{l}\text { Individual vs. } \\
\text { Collaborative } \\
\text { work }\end{array}$ & $\begin{array}{ll}- & \text { Lexis discussed } \\
\text { during LREs and } \\
\text { resolution of } \\
\text { LREs. } \\
\text { - } \\
\text { Tailor-made } \\
\text { vocabulary test }\end{array}$ & $\begin{array}{l}\text { Collaborative groups } \\
\text { resolved more lexical } \\
\text { LREs than individuals. } \\
\text { - Collaborative groups } \\
\text { performed significantly } \\
\text { better on the immediate } \\
\text { and delayed posttests. }\end{array}$ \\
\hline
\end{tabular}




\begin{tabular}{|c|c|c|c|c|}
\hline Study & $\mathrm{N}$ & Variables & Analysis & Key results \\
\hline $\begin{array}{l}\text { Philp, Walter, and } \\
\text { Basturkmen (2010) }\end{array}$ & $\mathrm{N}=7$ & $\begin{array}{l}\text { - } \text { Task type: } \\
\text { role play and } \\
\text { discussion } \\
\text { tasks. }\end{array}$ & $\begin{array}{l}\text { Focus of LREs } \\
\text { (lexis, grammar, } \\
\text { phonology) } \\
\text { - Factors affecting } \\
\text { frequency of } \\
\text { LREs. }\end{array}$ & $\begin{array}{l}\text { There was a total of } 33 \\
\text { LREs. } \\
\text { Most of the LREs } \\
(\mathrm{n}=23) \text { had a lexical } \\
\text { focus. } \\
\text { Task type and social } \\
\text { considerations affected } \\
\text { students' willingness to } \\
\text { attend to errors. }\end{array}$ \\
\hline $\begin{array}{l}\text { Heidari-Shahreza, } \\
\text { Dabaghi and } \\
\text { Kassaian (2012) }\end{array}$ & $\mathrm{N}=40$ & 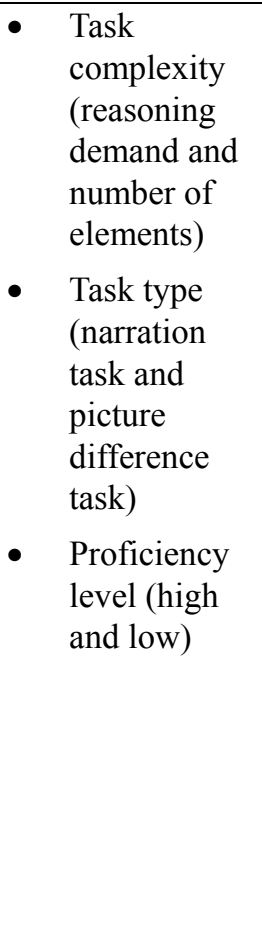 & $\begin{array}{l}\begin{array}{l}\text { Focus of LREs } \\
\text { (grammatical or } \\
\text { lexical) }\end{array} \\
\text { Relation between } \\
\text { increased task } \\
\text { complexity and } \\
\text { the occurrence of } \\
\text { LREs across high } \\
\text { and low levels of } \\
\text { proficiency) } \\
\text { Resolution of } \\
\text { LREs (correctly } \\
\text { resolved, } \\
\text { incorrectly } \\
\text { resolved, } \\
\text { unresolved) }\end{array}$ & 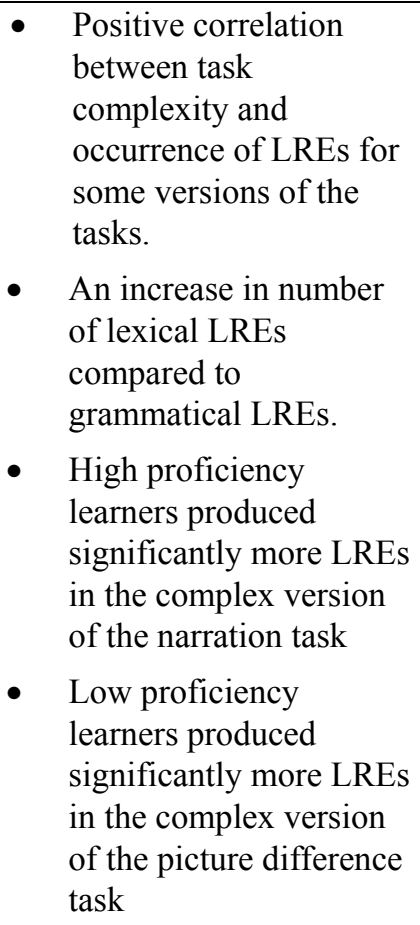 \\
\hline $\begin{array}{l}\text { Ismail and Abd. } \\
\text { Samad (2014) }\end{array}$ & $\mathrm{N}=76$ & $\begin{array}{l}\text { Task complexity } \\
\text { levels (+TRD \& } \\
\text {-TRD) }\end{array}$ & $\begin{array}{ll}\text { LREs with } \\
\text { negotiation of } \\
\text { form } \\
\text { Outcome of LREs } \\
\text { (correctly } \\
\text { resolved, } \\
\text { unresolved, } \\
\text { incorrectly } \\
\text { resolved) } \\
\text { Type of repair } \\
\text { practices } \\
\text { (self-initiated, } \\
\text { other-initiated, } \\
\text { self-repair, } \\
\text { other-repair) }\end{array}$ & $\begin{array}{l}\text { - } 528 \text { LREs were } \\
\text { generated involving } \\
\text { negotiation of form } \\
\text { - } \quad \text { Self-initiated and } \\
\text { self-repair practices } \\
\text { resulted in higher means } \\
\text { for successful resolution } \\
\text { of errors compared to } \\
\text { other-initiated and } \\
\text { other-repair practices. } \\
\text { The -TRD task resulted } \\
\text { in significantly higher } \\
\text { rates of correct } \\
\text { resolution of errors } \\
\text { compared to the }+ \text { TRD } \\
\text { task. }\end{array}$ \\
\hline
\end{tabular}

As shown in Table 1 the relationship between LREs and L2 development have been investigated in various contexts, with L2 development operationalised as the learning of pre-determined linguistic items (Adams, 2007; Lapkin, Swain, \& Smith, 2002) or any linguistic items that were discussed during the LREs (Williams, 1999; 
Swain \& Lapkin, 2001; Storch, 2008). Variables investigated in these studies included learner proficiency levels, task types, and task conditions. The impact of these variables on learner-learner interaction and L2 development were measured using tests, and analysis of learner-learner interaction.

Most of these studies were conducted in controlled classroom settings using a single task or several tasks. For example, sixty-five grade 6 students in French immersion classes participated in Swain and Lapkin's (2001) study. They were randomly assigned to one of two treatment groups. The first group carried out dictogloss tasks while the second group carried out jigsaw tasks. To investigate the impact the different task types had on the learners' task performance, their dialogues were transcribed and coded, and tailor-made dyad-specific questions were administered to assess the learners' knowledge of the linguistic items that were discussed during their LREs. Results indicated that dealing with the dictogloss task resulted in enhanced use of pronominal verbs during the LREs. Also, learners produced complex syntactic structures while dealing with the dictogloss task. Meanwhile, the jigsaw task resulted in significantly higher occurrences of LREs. This led the researchers to suggest that the open-ended nature of the task probably resulted in greater linguistic creativity.

Adams (2007) investigated the effectiveness of learner-learner interaction in the learning of 3 grammatical items: locative prepositions, past-tense and question forms. Twenty-five ESL learners participated in three collaborative tasks. Each task was designed to elicit the use of the three target structures. Tailor-made tests were then used to assess the amount of learning that occurred as a result feedback during learner-learner interaction. Results indicated that $59 \%$ of the items tested during the tailor-made tests were answered correctly.

Williams (1999) investigated the language production of 8 learners of 4 different levels of proficiency. This study examined the amount of LREs that occurred when learners were engaged in different types of activities with other learners. The activities ranged from structured work from the textbook to free conversation. Interestingly, learner-learner interaction also included 'learner-initiated requests to the teacher about language'. A total of 255 LREs were identified, transcribed and coded. Results of tailor-made post-tests indicated that when LREs were successfully resolved, learners correctly answered between $40 \%$ to $94 \%$ of the test items. It was also found that higher proficiency learners were also more likely to benefit from LREs than lower proficiency learners. Similarly, Poole (2005) in his study involving 19 learners found that learners engaged in LREs that focused on meaning $(89.8 \%)$ more than form $(10.2 \%)$.

Proficiency levels and task types were also the variables manipulated in Lapkin, Swain, and Smith's (2002) study involving eight grade 7 French immersion students. Data were elicited from four pairs of learners in a grade 7 French immersion program. Two task types were used: dictogloss and jigsaw tasks. For each task, the students were paired into one pair of average students, and one pair of a strong and an average student. The students' interaction was audio-recoded. Then, the LREs were identified, transcribed and coded in terms of their principal focus (i.e. lexis, grammar or discourse). Post-tests were conducted based on the use of pronominal verbs that occurred during the LREs. The results indicated that $66 \%$ of pronominal verb changes made by the reformulator were used correctly in the post-tests. Also, within each task, the stronger pairs created more contexts for pronominal verbs than their weaker counterparts. The stronger pairs also produced more detailed reformulations and more extensive collaborative dialogues. The researchers suggested that learning was facilitated by multiple opportunities provided in the stages of the tasks to reflect on pronominal verbs in a meaningful context. In particular, they found the reformulation stage to be most useful in providing learning opportunities.

Leeser (2004) also had task type and proficiency level as the independent variables. He used dictogloss and passage reconstruction tasks to determine the focus and outcome of LREs. He also placed the students in dyads of high-high, high-low, and low-low proficiency levels. He found that among the 42 participants, 138 LREs were generated and $60 \%$ of the LREs focused on grammar, with $77 \%$ of the LREs correctly resolved. He also found that dyads of high proficiency levels produced greater numbers of LREs compared to the other dyads.

Another study that investigated the effects of task type on learner attention to form was Garcia Mayo's (2002) study involving 14 university EFL learners in Spain. She analysed the learners' attention to form during two communicative tasks: dictogloss and text reconstruction. The learners' interaction in both tasks was codified and LREs were identified. Results of the study showed that learners' attention to form was task-dependent with eight times more LREs elicited during the text-reconstruction task compared to the dictogloss task. The researcher argued that perhaps the dictogloss was not so successful in eliciting LREs because of the difference in input modality, as learners had to focus on producing a coherent paragraph and not on discussing and reflecting on their language choices.

Task type was also the manipulated variable in Philp et al. (2010) study. They used role play and discussion tasks 
to gauge the focus of LREs and investigate the factors that affect frequency of LREs among seven participants. They found that most of the LREs had a lexical focus, and task type and social considerations affected the participants' willingness to attend to errors. Swain and Lapkin (2002) used a jigsaw story task with two participants. They found that LREs were produced in all three stages of the study- the pre-test writing stage (47 LREs), the noticing session (12 LREs) and the stimulated recall session (23 LREs). Unlike the results in Philp et al's (2010) study, most of the LREs were form-focused. Both learners showed improvements in their post individual writing test. Heidari-Shahreza et al (2012) took it a step further by investigating the effects of increasing task complexity levels in two different task types on frequency and outcome of LREs. This was achieved by manipulating the levels of reasoning demand and number of elements in a narration task and picture difference task. Results showed that increasing task complexity levels would also increase the occurence of LREs. There was also an increase in the number of lexical LREs compared to grammatical LREs. Ismail and Abd. Samad (2014) investigated the effects of manipulating task reasoning demand (TRD) on frequency of LREs with focus on form, outcomes of LREs and type of repair practices in LREs. They found that among the 76 participants, 528 LREs with focus on form were generated. Also, self-initiated and self-repair practices resulted in higher means for successful resolution of errors compared to other-initiated and other-repair practices, and the relatively low reasoning demand task (-TRD) task resulted in significantly higher rates of correct resolution of errors compared to the relatively high reasoning demand (+TRD) task.

Storch (2008) examined the LREs that learners produced in dyads while working on a text reconstruction task. In particular, the study investigated the learners' level of engagement during LREs, and the extent it affected language development. Level of engagement is operationalised by the number of turns in an LRE. An LRE could be composed of only two turns, or multiple turns. Storch (2008) argued that these differences in the lengths of LREs may reflect different levels of attention to language. Data were collected over a period of two weeks, with 22 participants. During the first week, students dealt with a text reconstruction task in dyads. Then, during the second week, students dealt with another version of the text reconstruction task, this time, individually. Learner-learner interaction was audio-recorded, transcribed and coded according to linguistic focus, correct/incorrect resolution, and quality of engagement. Quality of engagement was categorised as elaborate (E) and limited (L). An elaborate engagement (E) involved deliberation, confirmation requests, explanations and/or alternatives being discussed, while limited engagement (L) involved a mere correction of linguistic items, without further deliberation or explanation. Results of an analysis of learner performance based on items common to the two versions of the text reconstruction tasks indicated that elaborate engagement was more beneficial for the learners than limited engagement.

Kim (2008) and Malmqvist (2005) were interested in determining if working collaboratively on language tasks would indeed yield greater learning benefits as opposed to working individually. Malmqvist (2005) found that written texts produced collaboratively were more syntactically complex compared to the individually reconstructed texts, while Kim (2008) found that collaborative groups resolved more lexical LREs than individuals. Kim (2008) also found that collaborative groups performed significantly better on the immediate and delayed posttests compared to the participants working individually.

\section{Summary and Discussion}

All the studies discussed above indicated that LREs could have positive effects on L2 development, whether the linguistic items were pre-determined or otherwise.

\subsection{Repair Practices and LREs}

Frequency of LREs and outcomes of LREs could be indications of L2 learning "in process" (Gilabert, 2005) as learners try to establish closer and closer approximations to the L2. L2 learning "in process" is indicated by the noticing of errors and learner attempts to deal with them during LREs, and the correctly resolved LRE outcomes as opposed to incorrectly resolved or unresolved/abandoned LREs in the dyadic or group interaction. Kormos (1999) argues that self-repairs indicate learners' awareness of form and could be interpreted as learners' attempts to be accurate, while Gilabert (2005) contends that self-initiated LREs would indicate an awareness of gaps in language use. Thus, one indication of learning is correctly resolving linguistic problems that were dealt with during the LREs. This would be in line with Swain's Output Hypothesis $(1985,1998)$ and Schmidt's Noticing Hypothesis (1990) which suggest that negative feedback (i.e., any indication to a learner that an error has occurred in his language production) and noticing (i.e., bringing learners' attention to gaps in their language use) were found to play facilitative roles in assisting learners to identify errors in their language use and subsequently attempt to correct these errors through self- or other-repair practices. Thus, the repair practices during the LREs that occurred in the reviewed articles indicate that learners were noticing the gaps in their own or other learners' 
language use. By addressing these language gaps, learners further develop their interlanguage.

\subsection{Tasks and LRES}

Tasks provide a platform for discussion in dyads and groups. In their attempt to complete language tasks, learners would interact with each other. In the course of interacting, learners might notice gaps in their content knowledge and linguistic ability. Robinson (2007) highlights that in order to meet communication demands while completing complex tasks, learners would notice their language gaps, and attempt to solve linguistic problems by using negotiation and interactional feedback. Also, while interacting during complex tasks, learners would use various forms and structures to achieve their intended communicative function. As a result, the pushed output (Swain, 1995, 1998) would likely contribute to L2 development as reflected by correct resolutions of errors during interactional feedback. The studies reviewed clearly indicate that task variables, such as task complexity levels, could result in differing outcomes in aspects such as structural complexity of language production, grammatical items dealt with during LREs and rate of success in resolution of errors.

\section{Implications and Conclusion}

The studies reviewed highlight the importance of learner repair practices as they could have beneficial effects on L2 learning, as reflected by the successful outcomes of LREs and posttest results. Thus, teachers and other educational practitioners need to have a solid understanding of repair practices in order to provide training and practice for learners to negotiate form and meaning during learner-learner interaction. The studies also indicate that teachers need to recognise grammatical features that are problematic for their learners as reflected by the grammatical items focused on during LREs, or through other measures. This could then lead to teachers devising tasks that would encourage learners to deal with the intended grammatical items at different levels of cognitive processing. A variety of tasks is also required and these tasks should be based on, among others, learner linguistic needs, task effects on affective factors and the washback effects of examinations.

To gain greater insights into the nature of the LREs, future research could further analyse the exchanges that occurred during the LREs to gauge the techniques used to provide feedback. These techniques could, for instance, include explicit or implicit feedback and the different types of feedback (e.g., recast, clarification request, metalinguistic feedback) that fall under these two categories. Data analysis of feedback techniques could provide insights into the techniques that could result in significantly higher rates of success in L2 learning. It could also provide details of the nature of feedback techniques that are prevalent in learner-learner interaction. Further analysis could also include the number of turns that occurred during the LREs and how these impacted learning outcomes. In short, more detailed analysis of the nature of LREs that occurred during dyadic interaction could further assist researchers and practitioners in understanding interaction-oriented learning opportunities.

\section{References}

Adams, R. (2007). Do second language learners benefit from interacting with each other? In A. Mackey (Ed.), Conversational interaction in second language acquisition: A series of empirical studies (pp. 29-51). Oxford: Oxford University Press.

Donato, R. (2004). Aspects of collaboration in pedagogical discourse. Annual Review of Applied Linguistics, 24, 284-302. http://dx.doi.org/10.1017/s026719050400011x

Garcia-Mayo, M. (2002). The effectiveness of two form-focused tasks in advanced EFL pedagogy. International Journal of Applied Linguistics, 12(2), 156-175. http://dx.doi.org/10.1111/1473-4192.t01-1-00029

Gilabert, R. (2007). Effects of manipulating task complexity on self-repairs during L2 oral production. IRAL, 45, 215-240. http://dx.doi.org/10.1515/iral.2007.010

Kim, Y. (2008). The contribution of collaborative and individual tasks to the acquisition of L2 vocabulary. The Modern Language Journal, 92(1), 114-130. http://dx.doi.org/10.1111/j.1540-4781.2008.00690.x

Kormos, J. (1999). Monitoring and self-repair in L2. Language Learning, 49(2), 303-342. http://dx.doi.org/10.1111/0023-8333.00090

Lapkin, S., Swain, M., \& Smith, M. (2002). Reformulation and the learning of French pronominal verbs in a Canadian French immersion context. Modern Language Journal, 86(4), 485-507. http://dx.doi.org/10.1111/1540-4781.00157

Leeser, M. J. (2004). Learner proficiency and focus on form during collaborative dialogue. Language Teaching Research, 8, 55-81. http://dx.doi.org/10.1191/1362168804lr134oa

Long, M. (1990). Second language classroom research and teacher education. In C. Brumfit, \& R. Mitchell 
(Eds.), Research in the language classroom (pp. 161-170). ELT Documents 133.

Malmqvist, A. (2005). How does group discussion in reconstruction tasks affect written language output? Language Awareness, 14(2), 128-141. http://dx.doi.org/10.1080/09658410508668829

Philp, J., Walter, S., \& Basturkmen, H. (2010). Peer interaction in the foreign language classroom: What factors foster a focus on form? Language Awareness, 19(4), 261-279. http://dx.doi.org/10.1080/09658416.2010.516831

Poole, A. (2005). The kinds of forms learners attend to during focus on form information: A description of an advanced ESL writing class. Asian EFL Journal, 7(3), 1-13.

Robinson, P. (2007). Task complexity, theory of mind, and intentional reasoning: Effects on L2 speech production, interaction, uptake and perceptions of task difficulty. IRAL, 45, 193-213.

Samuda, V., \& Rounds, P. (1993). Critical Episodes: Reference points for analyzing a task in action. In G. Crookes, \& S. Gass (Eds.), Tasks and language learning: integrating theory and practice (pp. 125-138). Philadelphia: Multilingual Matters.

Schmidt, R. (1990). The role of consciousness in second language learning. Applied Linguistics, 11(2), 17-46.

Storch, N. (2008). Metatalk in a pair work activity: Level of engagement and implications for language development. Language Awareness, 17(2), 95-114. http://dx.doi.org/10.2167/la431.0

Swain, M. (1985). Communicative competence: Some roles of comprehensible input and comprehensible output and its development. In S. Gass, \& C. Madden (Eds.), Input in second language acquisition (pp. 235-253). Rowley, MA: Newbury House.

Swain, M. (1995). Three functions of output in second language learning. In G. Cook, \& B. Seidlhofer (Eds.), Principle and practice in applied linguistics: Studies in honor of H.G. Widdowson (pp. 125-144). Oxford: Oxford University Press.

Swain, M. (1998). Focus on form through conscious reflection. In C. Doughty, \& J. Williams (Eds.), Focus on form in classroom second language acquisition (pp. 64-81). Cambridge: Cambridge University Press.

Swain, M., \& Lapkin, S. (1998). Interaction and second language learning: Two adolescent French immersion students working together. Modern Language Journal, 82, 320-337. http://dx.doi.org/10.2307/329959

Swain, M., \& Lapkin, S. (2001). Focus on form through collaborative dialogue: Exploring task effects. In M. Bygate, P. Skehan, \& M. Swain (Eds.), Researching pedagogic tasks; second language learning, teaching, and testing. New York: Longman.

Swain, M., \& Lapkin, S. (2002). Talking it through: Two French immersion learners' response to reformulation. International Journal of Educational Research, 37, 285-304. http://dx.doi.org/10.1016/s0883-0355(03)00006-5

Williams, J. (1999). Learner-generated attention to form. Language Learning, 49(4), 583-625. http://dx.doi.org/10.1111/0023-8333.00103

\section{Copyrights}

Copyright for this article is retained by the author(s).

This is an open-access article distributed under the terms and conditions of the Creative Commons Attribution license (http://creativecommons.org/licenses/by/3.0/). 